\title{
Identification by PCR and evaluation of probiotic potential in yeast strains found in kefir samples in the city of Santa Maria, RS, Brazil
}

\author{
Daniela CASSANEGO ${ }^{1 *}$, Neila RICHARDS ${ }^{1}$, Patricia VALENTE ${ }^{2}$, Marcio MAZUTTI $^{1}$, \\ Maurício RAMÍREZ-CASTRILLON ${ }^{2}$
}

\begin{abstract}
Kefir is a product elaborated from the symbiotic fermentation of different microorganisms. The Kluyveromyces and Saccharomyces genera are the major representatives of the yeasts found in kefir microbiota. The only pobiotic yeast commercialized as an oral medication, is the Saccharomyces boulardii. The present work involved the microbiological quality examination of six kefir samples in the city of Santa Maria/RS, the yeasts isolation present in the samples and the identification of them by PCR (Polymerase chain reaction). Then, their probiotic potential was evaluated by in vitro technique. After that, microbiological analysis confirmed that kefir samples were suitable for consumption once the microbiological quality was established. Nineteen yeast strains were isolated from six different kefir samples; it was identified, by PCR analysis, but only three species were identified from these microorganisms in the present article: Saccharomyces cerevisiae, Hanseniospora uvarum and Kazachstania unispora. Nevertheless, by simulating the passage of isolated strains through the gastrointestinal environment, it was observed that they could not be considered probiotics. The results indicate that, in an isolated way, the yeast presents in kefir samples, in the city of Santa Maria, RS, can't be considered probiotics according to the tests performed.
\end{abstract}

Keywords: Saccharomyces boulardii; Saccharomyces cerevisiae; Hanseniospora; Kazachstania; in vitro.

Practical Application: Probiotic performance verification of yeast species isolated and identified in Kefir samples from the city of Santa Maria, RS.

\section{Introduction}

Kefir is a viscous, acid and slightly alcoholic solution, produced through fermented milk by means of "grains" as starter culture (Food and Agriculture Organization, 2003). The grains are composed of an inert matrix made up of polysaccharides and proteins. The matrix is densely populated by lactic acid bacteria species, acetic acid bacteria, and yeasts (Leite et al., 2012, 2013).

The traditional method of producing kefir is occurred by directly inoculation of grains in the milk. The milk may be whole, skimmed or semi skimmed and must have been gone through heat treatment equivalent to pasteurization or ultra-pasteurization. Subsequently, the milk is cooled at temperature $20-25{ }^{\circ} \mathrm{C}$ and then the inoculation occurs with kefir grains. The period of fermentation is $18-24$ hours at $20-25{ }^{\circ} \mathrm{C}$, then the grains are separated from the milk by filtering. The produced kefir is stored at $4{ }^{\circ} \mathrm{C}$ and it is ready for consumption (Otles \& Cagindi, 2003).

Fermented beverages with kefir grains can be consumed "in natura" or with other foods like fruit, cereals, honey, which makes it even more nutritious (Almeida et al., 2011). Studies carried out by Rodrigues et al. (2016) have shown the viability of also using kefir grains to produce beer, thus demonstrating the different functionalities of it as food.
Even though the majority of microorganisms in kefir grains are represented by bacteria, the yeasts are important for the microbiological balance and development of the physical-chemical and sensorial characteristics of the final product. According to Farnworth (2005), yeasts play an important role in the preparation of kefir, providing essential growth nutrients for acetic acid bacteria, such as amino acids and vitamins, and release metabolites that contribute to the flavour and mouthfeel of kefir, as ethanol and $\mathrm{CO}_{2}$.

Through its microbiological composition, kefir can be considered a complex probiotic product, holding in its composition live microorganisms able to improve the microbial intestinal balance, which produces benefits to the health of those who consume it (Weschenfelder et al., 2009). Some bacteria strains and yeasts found in kefir were recognized as probiotics, such as Leuconostoc mesenteroides and Saccharomyces cerevisiae (Leite et al., 2015).

Many definitions are used for the term probiotic, the most widely accepted one is that they are live microorganisms, which when consumed in adequate amounts, confer a health effect on the host (Food and Agriculture Organization, 2001). The majority of probiotics are bacteria, the lactic acid bacteria (LAB) are the 
most popular ones and used in many dairy products, such as the highly consumed fermented milk, cheese and vegetable-based foods (Chen et al., 2014).

Probiotic strains of Lactobacillus, Bifidobacterium and Saccharomyces have an extensive safety record for their consumption by the healthy population, in general, being recognized as GRAS (General Recognized as Safe) (Saad, 2011).

In the last decades, the yeasts have been considered as one of the microorganisms which present probiotic potential, however, showing a greater focus in the livestock production, the yeasts are being added in feed for ruminants, for example, increasing the weight of the animal and milk production (Fleet, 2007; Jacques \& Casaregola, 2008). The most important parameters to select the yeasts with probiotic potential and starter should be as follows: technological feasibility (growth at different temperatures, $\mathrm{pH}$, salt concentration, enzymatic activities and technological performance) and functional characteristics (survival in low $\mathrm{pH}$ and in the presence of bile salts, resistance to antibiotics, adhesion and/or permanence in the intestine) (Bevilacqua et al., 2009).

Despite the fact that the majority of the studies in terms of probiotic strains are related to the Saccharomyces boulardii specie, Martins et al. (2005b) affirm that other strains of Saccharomyces spp. or other yeast genera should, probably, have a similar or better probiotic activity than Saccharomyces boulardii. Arroyo-López et al. (2012) claim that nowadays there is a large interest in finding other yeast strains with probiotic characteristics. A great variety of microorganisms with potential use as probiotics have been isolated in kefir grains, however, bacteria are more studied (Golowczyc et al., 2011).

In view of the current interest in the yeast research with probiotic potential, and the presence of microorganisms in kefir, the aim of this article is to isolate and identify, through PCR analysis, the yeast species found in different kefir samples from Santa Maria/RS, Brazil. Moreover, evaluate the probiotic potential in vitro from the isolated strains.

\section{Material and methods}

The identification analyses from the isolated microorganisms were carried out in the Federal University of Rio Grande do Sul, in the Mycology Laboratory, Department of Microbiology, Institute of Health Sciences (ICBS/UFRGS), and the other analyses, in the Federal University of Santa Maria (UFSM). The analyses were conducted from November 2015 to August 2016.

\subsection{Obtaining of kefir samples}

The kefir samples were acquired in the city of Santa Maria, RS, they were kindly donate by locals who consume this product.

\subsection{Multiplication of samples}

The kefir samples were multiplied in sterilized UHT whole milk from the NINHO - Neslté brand (K1, K3, K4 and K5), and water with brown sugar (Mais Vita - Yoki), (K2), at room temperature $\left( \pm 25^{\circ} \mathrm{C}\right)$. Every 24 hours the mentioned culture media were renewed to maintain the microorganism colonies. In the sample $\mathrm{K} 6$ a mix was made of all kefir samples.

\subsection{Microbiological analysis of kefir samples}

In order to evaluate the microbiological quality of the kefir samples, it was performed Salmonella sp. analysis, thermotolerant and total coliforms, coagulase-positive Staphylococcus, total count of yeasts and lactic bacteria. Except for the analysis of lactic bacteria, which was performed following the American Public Health Association (2001) methodology and the yeast count, performed from the incubation on YM medium $(0.3 \%$ yeast extract, $0.3 \%$ malt extract, $0.5 \%$ peptone, $1 \%$ glucose, $2 \%$ Agar, $0.04 \%$ chloramphenicol at $\mathrm{pH} 4.0$ ) (Mattanna et al., 2014). the subsequent analysis were performed according to RDC 62/2003 (Brasil, 2003). The analysis referring to the microbiological parameters of kefir samples were performed in triplicate at dilutions from $10^{-1}$ to $10^{-10}$.

\subsection{Yeast isolation}

The methodology for the isolation of the yeast strain was described by Mattanna et al. (2014). The kefir samples were diluted in peptone water, up to $10^{-10}$, and it was performed surface plating, on YM medium ( $0.3 \%$ yeast extract, $0.3 \%$ malt extract, $0.5 \%$ peptone, $1 \%$ glucose, $2 \%$ Agar, $0.04 \%$ chloramphenicol at $\mathrm{pH} 4.0$ ). Petri dishes were incubated for 48 to 78 hours in greenhouse at $28^{\circ} \mathrm{C}$.

After growth, each visually different colony was plated, by depletion with platinum loop in a new Petri dish containing GYP medium ( $2 \%$ glucose, $2 \%$ Agar, $1 \%$ yeast extract, $1 \%$ peptone). Then, the dishes were incubated during 48 hours at $28^{\circ} \mathrm{C}$ and, after this period, a new depletion was performed, to confirm that in the Petri dish was present only one yeast colony. The isolated yeasts were pricked out in an inclined tube with GYP medium and kept at temperature of $4 \pm 1{ }^{\circ} \mathrm{C}$, with the tubes covered with sterile mineral oil.

\subsection{Identification of yeast isolates}

\section{DNA extraction}

The yeasts genomic DNA was extracted according to the methodology proposed by Ramírez-Castrillón et al. (2014). The quality of the extracted DNA was analysed on GelRed ${ }^{\circledR}$ stained $1 \%(\mathrm{w} / \mathrm{v})$ agarose gels and visualized under UV light with the Syngene photodocumentation system.

\section{PCR amplification}

The amplification of the large ribosomal subunit D1 / D2 domain (26S or ITS1-5.8S-ITS2 region) was performed, respectively, with primers NL1 / NL4 (O'Donnell, 1993) or ITS5 / ITS4 (White et al., 1990). The PCR reaction contained Taq polymerase (1U) (Invitrogen), $1 \mathrm{X}$ buffer, $\mathrm{MgCl} 2(3 \mathrm{mM})$, primers $(0.64 \mathrm{pmol} / \mathrm{uL}), \mathrm{dNTP}(10 \mathrm{mM})$ and DNA $(1 \mathrm{ng} / \mu \mathrm{L})$.

The amplification conditions were: initial denaturation at $94{ }^{\circ} \mathrm{C}$ for $5 \mathrm{~min}, 35$ cycles of denaturation at $94{ }^{\circ} \mathrm{C}$ for $15 \mathrm{sec}, 55^{\circ} \mathrm{C}$ for $45 \mathrm{sec}$, extension at $72{ }^{\circ} \mathrm{C}$ for $90 \mathrm{sec}$, and final 
extension at $72{ }^{\circ} \mathrm{C}$ for 6 min (Mattanna et al., 2014; RamírezCastrillón et al., 2014).

PCR products were verified in $1.5 \%(\mathrm{p} / \mathrm{v})$ agarose gels, stained with GelRed and visualized under UV light using the Syngene photodocumentation system. The 100 bp molecular weight marker was used to compare the size of the bands. Finally, the PCR products were purified using the ExoSap kit according to conditions established by the manufacturer.

\section{Yeast strains sequencing}

Sequences were obtained by the ABI-Prism 3100 Genetic Analyzer (Life Technologies Corp., USA), using protocols established by Ludwig Biotech Brazil (Alvorada, RS, Brazil). Sequences were edited, assembled and compared to sequences of TIPO strains deposited in GenBank using the Basic Local Alignment Search Tool (BLAST) algorithm. Identities between 99 and $100 \%$ allowed identification at the taxonomic level of species.

\subsection{Verifying probiotic potential of yeasts using in vitro tests}

Probiotic potential tests were performed in duplicate. The procedure was carried out twice in each isolated and identified yeast species.

\section{Simulation of gastric environment}

Yeast cells, isolated and identified, were multiplied in GYP broth (2\% glucose, $2 \%$ Agar, $0.5 \%$ yeast extract, $1 \%$ peptone) at $30{ }^{\circ} \mathrm{C}$ and $150 \mathrm{rpm}$. Cells were collected in the stationary phase by centrifugation ( 5 minutes at $3000 \mathrm{rpm}$ ), washed twice with sterile buffered saline and incubated in the simulated gastric environment at $37^{\circ} \mathrm{C}$ and $150 \mathrm{rpm}$ (Martins et al., 2005b).

In order to simulate the gastric environment the protocol initially described by Corcoran et al. (2007) with modifications made by Bonatsou et al. (2015) was adopted. The simulated gastric juice was prepared in a buffer solution ( $\mathrm{pH} 2.0)$ containing $\mathrm{NaCl}\left(2.05 \mathrm{~g} \mathrm{~L}^{-1}\right), \mathrm{KH}_{2} \mathrm{PO}_{4}\left(0.60 \mathrm{~g} \mathrm{~L}^{-1}\right), \mathrm{CaCl}_{2}\left(0.11 \mathrm{~g} \mathrm{~L}^{-1}\right)$ and potassium chloride $\left(0.37 \mathrm{~g} \mathrm{~L}^{-1}\right)$, the $\mathrm{pH}$ was adjusted in $1 \mathrm{M} \mathrm{HCl}$ and the medium was autoclaved at $121^{\circ} \mathrm{C}$ for $15 \mathrm{~min}$. Prior to use, pepsin (0.0133 g L-1) and lysozyme (0.01 g L- 1$)$ were added. Incubation occurred for $2.5 \mathrm{~h}$ at $37^{\circ} \mathrm{C}$ in an orbital shaker $(200 \mathrm{rpm})$ in order to simulate peristaltic movements. Finally, serial dilutions of the cultures were plated in YM medium and counted after incubation at $30^{\circ} \mathrm{C}$ for 48 hours.

\section{Pancreatic digestion}

The simulation of pancreatic digestion was performed using bile (3.0 $\mathrm{g} \mathrm{L}-1)$ and pancreatin $(0.1 \mathrm{~g} \mathrm{~L}-1)$ in a buffer solution at $\mathrm{pH} 8.0$ (adjusted with $1 \mathrm{M} \mathrm{HCl}$ ) consisting of $50.81 \mathrm{~g} \mathrm{~L}-1$ dibasic sodium phosphate heptahydrate and $8.5 \mathrm{~g} \mathrm{~L}-1 \mathrm{NaCl}$ stirred continuously at $200 \mathrm{rpm}$ for $3.5 \mathrm{~h}$ at $37^{\circ} \mathrm{C}$. Overall survival was obtained by comparison of the initial yeast counts $\left(\mathrm{CFU} / \mathrm{mL}^{-1}\right)$ at the beginning of the simulated gastric digestion and those cells recovered at the end of the simulated pancreatic digestion (Bonatsou et al., 2015).

\section{Results and discussion}

\subsection{Verification of microbiological samples quality}

Results of the microbiological analysis performed from the kefir samples in the city of Santa Maria, RS, are presented in Table 1.

The milk quality used in the manufacture of dairy products, as well as the conditions of production, are of great importance in order to obtain a healthy product (Caetano \& Montanhini, 2014).

Normative instructions n 46, October 23rd 2007, Technical Regulation on the Identity and Quality of Fermented Milks establishes that fermented milk considered kefir must contain at least $10^{4}$ UFC.mL ${ }^{-1}$ of yeasts and $10^{7}$ CFU.mL ${ }^{-1}$ of lactic bacteria, it can be observed in Table 1 that these parameters were found in all evaluated kefir samples (Brasil, 2007). The number of lactic bacteria found in this study corroborate with Wouters et al. (2002) who affirmed that these bacteria are the kefir predominant flora.

Similar results to the yeasts and lactic bacteria counts were found in studies performed by Garrote et al. (2001), in which the authors evaluated the microbiological composition of four kefir samples from Argentina. In a study carried out by Beshkova et al. (2003), lactic bacteria concentration in kefir was superior to $10^{10} \mathrm{CFU} . \mathrm{mL}^{-1}$, which is consistent with the results found in the present study.

Total coliforms were present in five kefir samples, it can be observe that the highest results of these microorganisms were found in water and brown sugar kefir samples, such results can be explained due to the presence of total coliforms both in the water and in the sugar, used for the multiplication of these samples. Presumably, the presence of total coliforms in the other samples has arisen through the manipulation of them.

Table 1. Microbiological evaluation of six kefir samples donated by locals of Santa Maria, RS. Results expressed as CFU.mL ${ }^{-1}$.

\begin{tabular}{|c|c|c|c|c|c|c|}
\hline Sample & Yeasts & Lactic bactéria & Total Coliforms & $\begin{array}{c}\text { Thermotolerant } \\
\text { Coliforms }\end{array}$ & $\begin{array}{c}\text { Coagulase positive } \\
\text { Staphylococcus }\end{array}$ & Salmonella \\
\hline $\mathrm{K} 1$ & $3.4 \times 10^{-11}$ & $3.7 \times 10^{-11}$ & $<1.0 \times 10^{-1}$ & $<1.0 \times 10^{-1}$ & $<1.0 \times 10^{-1}$ & Absence \\
\hline K2 & $5.4 \times 10^{-8}$ & $2.5 \times 10^{-7}$ & $1.27 \times 10^{-5}$ & $<1.0 \times 10^{-1}$ & $<1.0 \times 10^{-1}$ & Absence \\
\hline $\mathrm{K} 3$ & $5.2 \times 10^{-5}$ & $2.3 \times 10^{-9}$ & $2.4 \times 10^{-4}$ & $<1.0 \times 10^{-1}$ & $<1.0 \times 10^{-1}$ & Absence \\
\hline $\mathrm{K} 4$ & $5.6 \times 10^{-7}$ & $1.6 \times 10^{-11}$ & $8.0 \times 10^{-1}$ & $<1.0 \times 10^{-1}$ & $<1.0 \times 10^{-1}$ & Absence \\
\hline K5 & $4.7 \times 10^{-5}$ & $8.8 \times 10^{-10}$ & $1.5 \times 10^{-3}$ & $<1.0 \times 10^{-1}$ & $<1.0 \times 10^{-1}$ & Absence \\
\hline K6 & $3.8 \times 10^{-6}$ & $2.6 \times 10^{-11}$ & $1.6 \times 10^{-2}$ & $<1.0 \times 10^{-1}$ & $<1.0 \times 10^{-1}$ & Absence \\
\hline
\end{tabular}

K1: milk kefir; K2: water kefir; K3: kefir initially of water that was grown in milk kefir later; K4: milk kefir; K5: milk kefir; K6: mixture of all kefir samples, como citado no item 2.2- Multiplication of samples. 
Thermotolerant coliforms, coagulase positive Staphylococcus and Salmonella sp. were not present, which are satisfactory results since the Normative instruction $N^{\circ} .62$, august $26^{\text {th }} 2003$ (Brasil, 2003), predicts the absence of these microorganisms in kefir samples.

\subsection{Identification of isolates}

Table 2 shows the yeast species found in kefir samples from the city of Santa Maria, RS.

Microbial analysis from three different kefir grains of Brazil, by PCR-DGGE, performed by Leite et al. (2012), showed Lactobacillus kefiranofaciens and Lactobacillus kefiri to be the major bacterial populations in all three grains and the yeast community was dominated by Saccharomyces cerevisiae, in accordance with the yeast species of the kefir samples evaluated in the present study.

Another study, previously performed in Brazil with the aim of identifying the microbial profile of kefir sample cultivated in an aqueous fermentation of brown sugar found the following yeast species: Saccharomyces cerevisiae, Candida colliculosa, Toruspola delbruechii, Candida inconspicua, Candida magnoliae, Kloekera sp., Candida famata, Kluyveromices lactis, K. marxianus and Candida kefir (Bergmann et al., 2010).

Uraz et al. (2012) isolated yeasts from kefir of Turkey. Altogether, 66 different species of these microorganisms were found, $51 \%$ of the yeasts found were Candida kefyr specie, $33 \%$

Table 2. Genetic identification of the species with their edited sequences assembled and compared to sequences of TIPO strains deposited in GenBank using the Basic Local Alignment Search Tool (BLAST) algorithm. Identities between 99 and 100\% allowed identification at the taxonomic level of species.

\begin{tabular}{cccr}
\hline Sample & Specie & Identity & Accession \\
\hline K1a & Saccharomyces cerevisiae & $99 \%$ & KF81001.2 \\
K1b & Saccharomyces cerevisiae & $99 \%$ & JF757233.1 \\
K1c & Saccharomyces cerevisiae & $99 \%$ & HQ262396.1 \\
K1d & Saccharomyces cerevisiae & $99 \%$ & HQ262394.1 \\
K1e & Saccharomyces cerevisiae & $99 \%$ & GU565204.1 \\
KIf & Saccharomyces cerevisiae & $99 \%$ & GQ121691.1 \\
K2a & Hanseniospora uvarum & $100 \%$ & EF55O176.1 \\
K2b & Saccharomyces cerevisiae & $99 \%$ & GQ121685.1 \\
K3a & Kazachstania unispora & $99 \%$ & AY048158.1 \\
K3b & Kazachstania unispora & $99 \%$ & AY048158.1 \\
K3c & Saccharomyces cerevisiae & $99 \%$ & GQ121549.1 \\
K4a & Kazachstania unispora & $99 \%$ & AY007912.1 \\
K4b & Saccharomyces cerevisiae & $99 \%$ & FJ770500.1 \\
K4c & Saccharomyces cerevisiae & $99 \%$ & KJ530642.1 \\
K5a & Saccharomyces cerevisiae & $99 \%$ & CP009950.1 \\
K5b & Saccharomyces cerevisiae & $99 \%$ & KP064124.1 \\
K6a & Kazachstania unispora & $99 \%$ & AY007912.1 \\
K6b & Saccharomyces cerevisiae & $99 \%$ & KM655850.1 \\
K6c & Kazachstania unispora & $100 \%$ & AY007912.1 \\
\hline
\end{tabular}

K1: milk kefir; K2: water kefir; K3: kefir initially of water that was grown in milk kefir later; K4: milk kefir; K5: milk kefir; K6: mixture of all kefir samples. Lowercase letters after the terms mean different yeasts isolated.
Candida famata and only $2 \%$ from the yeast present in the evaluated kefir were from the $S$. cerevisiae specie.

Microorganisms from kefir of different regions in Turkey were found, Kluyveromices marxianus and Kluyveromices dobzhanskii were the most representative yeast species (Taş et al., 2012), Kluyveromices marxianus was also the most found yeast specie in Tibetan kefir (Jianzhong et al., 2009).

Authors isolated and identified microorganisms present in kefir obtained from Bali, in a total of 115 isolates, $68.7 \%$ were lactic acid bacteria and $31.3 \%$ were yeast, having Candida famata as the largest representative of them (Suriasih et al., 2012).

The microbial diversity of water kefir, made from a mixture of water, dried figs, lemon and sucrose was studied by Gulitz et al. (2011), the authors found the yeast Zygotorulaspora florentina as being the more predominant one in this type of cultive.

Even though articles evidenced a wide diversity of yeast species present in kefir, only three species of these microorganisms were found in the present article; Saccharomyces cerevisiae, Hanseniospora uvarum and Kazachstania unispora. Considering that the type of milk and the culture may influence the microbiological variety of Kefir, this fact may be the reason for the presence of only two yeast species.

\subsection{Evaluation of probiotic potential in isolated yeasts}

Saccharomyces boulardii, known as the main probiotic yeast strain, has been used for many years as an oral biotherapeutic agent for treating a range of diarrheal disorders, such as diarrhea associated with antibiotic use, acute gastroenteritis in adults and children, diarrhea in probe-fed patients, chronic diarrhea in HIV-infected patients, and has been found to be useful against enteropathogenic agents (Martins et al., 2005a; Czerucka et al., 2007; Fleet, 2007; Pennacchia et al., 2008).

However, authors have been researching on the probiotic potential of other strains and yeast species, for instance in the study carried out by Diosma et al. (2014), in which yeast isolated from kefir in Argentina were identified and evaluated in relation to their probiotic potential. 34 yeast strains were isolated and identified by means of classical microbiological and molecular-genetic methods, out of them, 13 isolates showed resistance to bile salts. Also, K. marxianus CIDCA 8154 and S. cerevisiae CIDCA 8112 evidenced the capacity to adhere to epithelial intestine cells and to survive passage through the gastrointestinal tract of Balb/c mice. Authors concluded that further studies are still required; however, the results obtained here should nevertheless be useful for the development of new probiotic products based on the different strains of yeast isolated from kefir.

Romanin et al. (2010) evaluated the anti-inflammatory activity of 21 yeasts, from the genera Saccharomyces, Kluyveromyces and Issatchenkia, isolated from kefir, were $100 \%$ effective to inhibit the inflammation in the intestinal epithelium, attesting the importance of studying yeasts which are a part of microbial flora of kefir.

Pedersen et al. (2012) identified and evaluated the probiotic potential of yeasts isolated from Fura, an African spontaneously 
fermented cereal. They were tested for the ability to survive in bile salts, low $\mathrm{pH}$, growth on epithelial cells and transepithelial electrical resistance. As a result, new yeasts with probiotic potential were found in the study, the evaluated and characterized species were Candida krusei, Kluyveromyces marxianus, Candida tropicalis, Candida rugosa and Trichosporon asahii.

A new lineage from S. cerevisiae, denominated as UFMG 905, was isolated from Brazilian cachaça evaluated in relation to its probiotic potential by Martins et al. (2005b). The results showed that the yeast was able to colonize and survive in the gastrointestinal tract of mice and to protect them against experimental infections of Salmonella enterica serotype typhimurium and Clostridium difficile. Later on, in a new study conducted by the same authors, the results showed that S. cerevisiae UFMG 905 was able to reduce the translocation of Salmonella Typhimurium and stimulate the immune system of mice (Martins et al., 2007).

Perricone et al. (2014) isolated yeasts from Altamura (south region of Italy) and, satisfactory results were found when the authors tested the probiotic capacity of them; 18 isolates underwent a selection for their probiotic traits however, only 2 isolates (Saccharomyces cerevisiae strain 2 and Saccharomyces cerevisiae strain 4) were selected and analysed in relation to the simulation of the gastric transit; these isolates showed a trend similar to Saccharomyces Boulardii when it comes to its probiotic potential.

Although several studies have shown that yeasts may present probiotic potential, in the present study none of the 19 strains evaluated presented this benefit, considering the in vitro analyses, none of the isolated yeast strains were able to survive the passage through pancreatic digestion, in all analyses performed; it was observed a great decrease in the number of these microorganisms. Thus they cannot be considered as probiotics since the amount of probiotic microorganisms that are able to survive is essential for its functionality and it will depend on the strain of microorganism selected during the process of product's manufacturing. (Tomaselli et al., 2011). Table 3 shows the results of probiotic potential of yeasts used in vitro tests.

Recent study carried out by Kim et al. (2017) affirmed that kefir administered in mice improved and modulated the gut microbiota, which prevents obesity through promoting fatty acid oxidation. Such fact emphasises the benefits of kefir consumption as a symbiotic system and not only some selected microorganisms.

Several studies confirm the beneficial effects of kefir, such as the capacity to modulate the intestinal mucosal immune response in mice, enhance the phagocytic activity of peritoneal and pulmonary macrophage, furthermore, the capacity to enhance the mucosal immune system in distal sites (bronchial tissue) (Vinderola et al., 2005a; Vinderola et al., 2005b). In studies performed by Vinderola et al. (2005a, b, 2006), the authors observed that different components of kefir present an in vivo role role as oral biotherapeutic substances capable of stimulating immune cells of the innate immune system or to promote cell-mediated immune responses against tumours and also against intracellular pathogenic infections.
Table 3. results of probiotic potential of yeasts used in vitro tests.

\begin{tabular}{cccc}
\hline Sample & Specie & $\begin{array}{c}\text { Simulation } \\
\text { of gastric } \\
\text { environment }\end{array}$ & $\begin{array}{c}\text { Pancreatic } \\
\text { digestion }\end{array}$ \\
\hline K1a & Saccharomyces cerevisiae & + & - \\
K1b & Saccharomyces cerevisiae & + & - \\
K1c & Saccharomyces cerevisiae & + & - \\
K1d & Saccharomyces cerevisiae & + & - \\
K1e & Saccharomyces cerevisiae & + & - \\
KIf & Saccharomyces cerevisiae & + & - \\
K2a & Hanseniospora uvarum & + & - \\
K2b & Saccharomyces cerevisiae & - & - \\
K3a & Kazachstania unispora & + & - \\
K3b & Kazachstania unispora & + & - \\
K3c & Saccharomyces cerevisiae & - & - \\
K4a & Kazachstania unispora & + & - \\
K4b & Saccharomyces cerevisiae & + & - \\
K4c & Saccharomyces cerevisiae & + & - \\
K5a & Saccharomyces cerevisiae & + & - \\
K5b & Saccharomyces cerevisiae & + & - \\
K6a & Kazachstania unispora & - & - \\
K6b & Saccharomyces cerevisiae & + & - \\
K6c & Kazachstania unispora & - & - \\
\hline K1 & Kefl & - \\
\hline
\end{tabular}

K1: milk kefir; K2: water kefir; K3: kefir initially of water that was grown in milk kefir later; K4: milk kefir; K5: milk kefir; K6: mixture of all kefir samples. (+ positive results; - negative results). Lowercase letters after the terms mean different yeasts isolated.

\section{Conclusion}

Even though there were quantitatively a large variety of yeasts, when performing the identification analyses of the 19 isolated strains by PCR, only three species of these microorganisms were identified: Saccharomyces cerevisiae, Hanseniospora uvarum and Kazachstania unispora.

Upon analyzing the probiotic potential in vitro, by the passage of the 19 strains through the simulated gastro-intestinal tract, it is possible to observe that the yeasts were not efficient in the passage through pancreatic digestion, and therefore, they are not considered probiotic. However, further studies with yeast isolated from kefir should be carried out considering that some already published studies demonstrate the possible probiotic power of some of these microorganisms.

\section{References}

Almeida, F. A., Ângelo f. F., \& Silva, S. L. (2011). Análise sensorial e microbiológica de kefir artesanal produzido a partir de leite de cabra e de leite de vaca. Revista do Instituto de Laticínios Cândido Tostes, 66, 51-56.

American Public Health Association - APHA. (2001). Compendium of methods for the microbiological examination of foods (4th ed., 676 p.). Washington: APHA.

Arroyo-López, F. N., Romero-Gil, V., Bautista-Gallego, J., RodríguezGómez, F., Jiménez-Díaz, R., García-García, P., Querol, A., \& Garrido-Fernández, A. (2012). Yeasts in table olive processing: desirable or spoilage microorganisms? International Journal of Food Microbiology, 160(1), 42-49. PMid:23141644. http://dx.doi. org/10.1016/j.ijfoodmicro.2012.08.003. 
Bergmann, R. S. O., Pereira, M. A., Veiga, S. M. O. M., Schneedorf, J. M., Oliveira, N. M. S., \& Fiorini, S. E. (2010). Microbial profile of a kefir sample preparations: grains in natura and lyophilized and fermented suspension. Ciência e Tecnologia de Alimentos, 30(4), 1022-1026. http://dx.doi.org/10.1590/S0101-20612010000400029.

Beshkova, D. M., Simova, E. D., Frengova, G. I., Simov, Z. I., \& Dimitrov, Z. P. (2003). Production of volatile aroma compounds by Kefir starter cultures. International Dairy Journal, 13(7), 529-535. http://dx.doi. org/10.1016/S0958-6946(03)00058-X.

Bevilacqua, A., Perricone, M., Cannarsi, M., Corbo, M. R., \& Sinigaglia, M. (2009). Technological and spoiling characteristics of the yeast microflora isolated from Bella Di Cerignola table olives. International Journal of Food Science \& Technology, 44(11), 2198-2207. http:// dx.doi.org/10.1111/j.1365-2621.2009.02060.x.

Bonatsou, S., Benítez, A., Rodríguez-Gómez, F., Panagou, E. Z., \& Arroyo-López, F. N. (2015). Selection of yeasts with multifunctional features for application as starters in natural black table olive processing. Food Microbiology, 46, 66-73. PMid:25475268. http:// dx.doi.org/10.1016/j.fm.2014.07.011.

Brasil. Ministério da Agricultura, Pecuária e Abastecimento. (2003). Instrução Normativa no 62 de 26 de agosto de 2003. Métodos analíticos oficiais para análises microbiológicas para controle de produtos de origem animal e água. Diário Oficial [da] República Federativa do Brasil.

Brasil. Ministério da Agricultura, Pecuária e Abastecimento. (2007). Instrução Normativa no 46, de 23 de outubro de 2007. Regulamento Técnico de Identidade e Qualidade de Leites Fermentados. Diário Oficial [da] República Federativa do Brasil.

Caetano, D. R., \& Montanhini, M. T. M. (2014). Análise microbiológica de leite fermentado kefir produzido com leite contaminado por Escherichia coli. Revista Brasileira de Pesquisa em Alimentos, 5(1), 33-38. http://dx.doi.org/10.14685/rebrapa.v5i1.158.

Chen, P., Zhang, Q., Dang, H., Liu, X., Tian, F., Zhao, J., Chen, Y., Zhang, H., \& Chen, W. (2014). Screening for potential new probiotic based on probiotic properties and a-glucosidase inhibitory activity. Food Control, 35(1), 65-72. http://dx.doi.org/10.1016/j.foodcont.2013.06.027.

Corcoran, B. M., Stanton, C., Fitzgerald, G. F., \& Ross, R. P. (2007). Growth of probiotic lactobacilli in the presence of oleic acid enhances subsequent survival in gastric juice. Microbiology, 153(Pt 1), 291-299. PMid:17185558. http://dx.doi.org/10.1099/mic.0.28966-0.

Czerucka, D., Piche, T., \& Rampal, P. (2007). Review article: yeast as probiotics: Saccharomyces boulardii. Alimentary Pharmacology and Therapeutics, 26, 767-778. http://dx.doi.org/10.1111/j.13652036.2007.03442.x/full.

Diosma, G., Romanin, D. E., Rey-Burusco, M. F., Londero, A., \& Garrote, G. L. (2014). Yeasts from kefir grains: isolation, identification, and probiotic characterization. World Journal of Microbiology \& Biotechnology, 30(1), 43-53. PMid:23824665. http://dx.doi.org/10.1007/ s11274-013-1419-9.

Farnworth, E. R. (2005). Kefir: a complex probiotic. Food Science e Technology Bulletin: Functional Foods, 2, 1-17. http://dx.doi. org/10.1616/1476-2137.13938.

Fleet, G. H. (2007). Yeasts in foods and beverages: impact on product quality and safety. Current Opinion in Biotechnology, 18(2), 170-175. PMid:17275276. http://dx.doi.org/10.1016/j.copbio.2007.01.010.

Food and Agriculture Organization- FAO. (2001). Evaluation of health and nutritional properties of probiotics in food including powder milk with live lactic acid bacteria (34 p.). Rome: FAO.

Food and Agriculture Organization- FAO. (2003). CODEX Standard for Fermented Milks (2nd ed.). Rome: FAO.
Garrote, G. L., Abraham, A. G., \& De Antoni, G. L. (2001). Chemical and microbiological characterisation of kefir grains. The Journal of Dairy Research, 68(4), 639-652. PMid:11928960. http://dx.doi. org/10.1017/S0022029901005210.

Golowczyc, M. A., Silva, J., Teixeira, P., De Antoni, G. L., \& Abraham, A. G. (2011). Cellular injuries of spray-dried Lactobacillus spp. isolated from kefir and their impact on probiotic properties. International Journal of Food Microbiology, 144(3), 556-560. PMid:21144610. http://dx.doi.org/10.1016/j.ijfoodmicro.2010.11.005.

Gulitz, A., Stadie, J., Wenning, M., Ehrmann, M. A., \& Vogel, R. F. (2011). The microbial diversity of water kefir. International Journal of Food Microbiology, 151(3), 284-288. PMid:22000549. http://dx.doi. org/10.1016/j.ijfoodmicro.2011.09.016.

Jacques, N., \& Casaregola, S. (2008). Safety assessment of dairy microorganisms: the hemiascomycetous yeasts. International Journal of Food Microbiology, 126(3), 321-326. PMid:17854934. http://dx.doi. org/10.1016/j.ijfoodmicro.2007.08.020.

Jianzhong, Z., Liu, X., Jiang, H., \& Dong, M. (2009). Analysis of the microflora in Tibetan kefir grains using denaturing gradient gel electrophoresis. Food Microbiology, 26(8), 770-775. PMid:19835760. http://dx.doi.org/10.1016/j.fm.2009.04.009.

Kim, D. H., Kim, H., Jeong, D., Kang, II-B., Chon, J-W., Kim, H-S., Song, K-Y., \& Seo, K-H. (2017). Kefir alleviates obesity and hepatic steatosis in high-fat diet-fed mice by modulation of gut microbiota and mycobiota: targeted and untargeted community analysis with correlation of biomarkers. The Journal of Nutritional Biochemistry, (In Press). http://dx.doi.org/10.1016/j.jnutbio.2017.02.014.

Leite, A. M. O., Mayo, B., Rachid, C. T. C. C., Peixoto, R. S., Silva, J. T., Paschoalin, V. M. F., \& Delgado, S. (2012). Assessment of the microbial diversity of Brazilian kefir grains by PCR- DGGE and pyrosequencing analysis. Food Microbiology, 31(2), 215-221. PMid:22608226. http://dx.doi.org/10.1016/j.fm.2012.03.011.

Leite, A. M. O., Miguel, M. A., Peixoto, R. S., Rosado, A. S., Silva, J. T., \& Paschoalin, V. M. (2013). Microbiological, technological and therapeutic properties of kefir: a natural probiotic beverage. Brazilian Journal of Microbiology, 44(2), 341-349. PMid:24294220. http://dx.doi.org/10.1590/S1517-83822013000200001.

Leite, A. M. O., Miguel, M. A. L., Peixoto, R. S., Ruas-Madiedo, P., Paschoalin, V. M. F., Mayo, B., \& Delgado, S. (2015). Probiotic potential of selected lactic acid bacteria strains isolated from Brazilian kefir grains. Journal of Dairy Science, 98(6), 3622-3632. PMid:25841972. http://dx.doi.org/10.3168/jds.2014-9265.

Martins, F. S., Barbosa, F. H. F., Penna, F. J., Rosa, C. A., Nardi, R. M. D., Neves, M. J., \& Nicoli, J. R. (2005b). Estudo do potencial probiótico de linhagens de Saccharomyces cerevisiae através de testes in vitro. Revista de Biologia e Ciências da Terra, 5, 14-20.

Martins, F. S., Nardi, R. M., Arantes, R. M., Rosa, C. A., Neves, M. J., \& Nicoli, J. R. (2005a). Screening of yeasts as probiotic based on capacities to colonize the gastrointestinal tract and to protect against enteropathogen challenge in mice. The Journal of General and Applied Microbiology, 51(2), 83-92. PMid:15942869. http:// dx.doi.org/10.2323/jgam.51.83.

Martins, F. S., Rodrigues, A. C., Tiago, F. C., Penna, F. J., Rosa, C. A., Arantes, R. M., Nardi, R. M., Neves, M. J., \& Nicoli, J. R. (2007). Saccharomyces cerevisiae strain 905 reduces the translocation of Salmonella enterica serotype Typhimurium and stimulates the immune system in gnotobiotic and conventional mice. Journal of Medical Microbiology, 56(Pt 3), 352-359. PMid:17314366. http:// dx.doi.org/10.1099/jmm.0.46525-0.

Mattanna, P. R., Poli, J., Richards, N. S. P. S., Daboi, T., Scroferneker, M. L., Pastore, A. P., Corcao, G., Bertoldi, F., Deschamps, F. C., \& Valente, 
P. (2014). Lipid profile and antimicrobial activity of microbial oils from 16 oleaginous yeasts isolated from artisanal cheese. Revista Brasileira de Biociências, 12, 121-126.

O’Donnell, K. (1993). Fusarium and its near relatives. In D. R. Reynolds \& J. W. Taylor (Eds.), The Fungal Holomorph: Mitotic, Meiotic and Pleomorphic Speciation in Fungal Systematics (pp. 225-233). Wallingford: CAB International.

Otles, S., \& Cagindi, O. (2003). Kefir: A probiotic dairy-composition, nutritional and therapeutic aspects. Pakistan Journal of Nutrition, 2, 54-59.

Pedersen, L. L., Owusu-Kwarteng, J., Thorsen, L., \& Jespersen, L. (2012). Biodiversity and probiotic potential of yeasts isolated from Fura, a West African spontaneously fermented cereal. International Journal of Food Microbiology, 159(2), 144-151. PMid:23072700. http://dx.doi. org/10.1016/j.ijfoodmicro.2012.08.016.

Pennacchia, C., Blaiotta, G., Pepe, O., \& Villani, F. (2008). Isolation of Saccharomyces cerevisiae strains from different food matrices and their preliminary selection for a potential use as probiotics. Journal of Applied Microbiology, 105, 1919-1928. http://dx.doi. org/10.1111/j.1365-2672.2008.03968.x.

Perricone, M., Bevilacqua, A., Corbo, M. R., \& Sinigaglia, M. (2014). Technological characterization and probiotic traits of yeasts isolated from Altamura sourdough to select promising microorganisms as functional starter cultures for cereal-based products. Food Microbiology, 38, 26-35. PMid:24290622. http://dx.doi.org/10.1016/j. fm.2013.08.006.

Ramírez-Castrillón, M., Mendes, S. D. C., Inostroza-Ponta, M., \& Valente, P. (2014). (GTG) 5 MSP-PCR fingerprinting as a technique for discrimination of wine associated yeasts? PLoS One, 9(8), e105870. PMid:25171185. http://dx.doi.org/10.1371/journal.pone.0105870.

Rodrigues, K. L., Araújo, T. H., Schneedorf, J. M., Ferreira, C. S., Moraes, G. O. I., Coimbra, R. S., \& Rodrigues, M. R. (2016). A novel beer fermented by kefir enhances antiinflammatory and anti-ulcerogenic activities found isolated in its constituents. Journal of Functional Foods, 21, 58-69. http://dx.doi.org/10.1016/j.jff.2015.11.035.

Romanin, D., Serradell, M., González, D. M., Lausada, N., Garrote, G. L., \& Rumbo, M. (2010). Downregulation of intestinal epithelial innate response by probiotic yeasts isolated fron kefir. International Journal of Food Microbiology, 140(2-3), 102-108. PMid:20471126. http://dx.doi.org/10.1016/j.ijfoodmicro.2010.04.014.
Saad, S. M. I. (2011). Probióticos e prebióticos em alimentos: fundamentos e aplicações tecnológicas. São Paulo: Livraria Varela.

Suriasih, K., Aryanta, W. R., Mahardika, G., \& Astawa, N. M. (2012). Microbiological and chemical properties of kefir made of Bali Cattle milk. Food Science and Quality Management, 6, 12-22.

Taş, T. K., Ekinci, F. Y., \& Guzel-Seydim, Z. B. (2012). Identification of microbial flora in kefir grains produced in Turkey using PCR. International Journal of Dairy Technology, 65(1), 126-131. http:// dx.doi.org/10.1111/j.1471-0307.2011.00733.x.

Tomaselli, L. P. C., Pedroso, P. Z., Foppa, T., \& De Oliveira, L. (2011). Viabilidade e sobrevivência da bactéria Bifidobacterium em fluido gástrico simulado. Evidência, 11(2), 7-14.

Uraz, G., Akkuzu, S., Özcan, S., \& Sevima, I. (2012). Isolation of yeast from microflora of kefir. Australian Journal of Biotechnology, 16(1), 19-48. http://dx.doi.org/10.1016/j.jbiotec.2012.07.119.

Vinderola, C. G., Duarte, J., Thangavel, D., Perdigón, G., Farnworth, E., \& Matar, C. (2005a). Immunomodulating capacity of kefir. The Journal of Dairy Research, 72(2), 195-202. PMid:15909685. http:// dx.doi.org/10.1017/S0022029905000828.

Vinderola, C. G., Duarte, J., Thangavel, D., Perdigón, G., Farnworth, E., \& Matar, C. (2005b). Distal mucosal site stimulation by kefir and duration of the immune response. European Journal of Inflammation, 3(2), 63-73. http://dx.doi.org/10.1177/1721727X0500300203.

Vinderola, C. G., Perdigón, G., Duarte, J., Thangavel, D. G., Farnworth, E., \& Matar, C. (2006). Effects of kefir fractions on innate immunity. Immunobiology, 211(3), 149-156. PMid:16530082. http://dx.doi. org/10.1016/j.imbio.2005.08.005.

Weschenfelder, S., Wiest, J. M., \& Carvalho, H. H. C. (2009). Atividade anti-Escherichia coli em kefir e soro de kefir tradicionais. Revista do Instituto de Laticínios. Cândido Tostes, 34(367/368), 48-55.

White, T. J., Bruns, T. D., Lee, S. B., \& Taylor, J. W. (1990). Amplification and direct sequencing of fungal ribosomal RNA genes for phylogenetics. In M. A. Innis, D. H. Gelfand, J. J. Sninsky \& T. J. White (Eds.), PCR protocols (pp. 315-322). San Diego: Academic Press.

Wouters, J. T. M., Ayad, E. H., Hugenholtz, J., \& Smit, G. (2002). Microbes from raw milk for fermented dairy products. International Dairy Journal, 12(2-3), 91-109. http://dx.doi.org/10.1016/S09586946(01)00151-0. 